\title{
Severe soft tissue infection in a patient with type 2 diabetes mellitus caused by Serratia marcescens as single pathogen
}

\author{
ANNA L BISCOE, ${ }^{1}$ LUKMAN HAKEEM²
}

\begin{abstract}
Serratia marcescens is a rare cause of soft tissue infection. However, it has been increasingly recognised as a pathogen causing infection in both immunocompromised patients and in patients in an intensive treatment unit setting. Here we describe an elderly patient with type 2 diabetes mellitus presenting with severe necrotic soft tissue infection due to $S$. marcescens acquired in the community. The literature on $S$. marcescens soft tissue infection is reviewed and management is discussed.
\end{abstract}

Key words: S. marcescens, soft tissue infection, cellulitis, necrotising fasciitis, diabetes

\section{Case report}

An 80-year-old woman with a background of type 2 diabetes mellitus, heart failure, coronary artery bypass graft, atrial fibrillation, chronic renal failure, hypertension and breast cancer was admitted with a one-week history of worsening lower left limb pain, erythema and reduced mobility.

She was initially stable on admission but rapidly deteriorated within an hour. She was febrile at $38^{\circ} \mathrm{C}$ and her blood pressure dropped to $93 / 50 \mathrm{mmHg}$. She was tachycardic at 110 beats $/ \mathrm{min}$ and tachypnoeic at 26 breaths/min with saturations of $94 \%$ on $28 \%$ oxygen. Capillary refill time was 4 seconds. Her left leg was erythematous, warm and tender with significant swelling and she had a number of bullae around the mid-thigh.

Arterial blood gases showed hypoxia and a lactate of 5.1 $\mathrm{mmol} / \mathrm{L}$. Blood results showed acute on chronic renal failure (urea $14 \mathrm{mmol} / \mathrm{L}$, creatinine $156 \mu \mathrm{mol} / \mathrm{L}$ ), white cell count of $11.9 \times 10 \% / \mathrm{L}$ with neutrophilia, platelet count of $77 \times 10 \% / \mathrm{L}$, C-reactive protein $309 \mathrm{mg} / \mathrm{L}$ and deranged coagulation with an International Ratio (INR) of 10 (the patient was on warfarin).

FY2 Doctor, Aberdeen Royal Infirmary, UK

2 Consultant in Infectious Diseases and Acute Medicine Aberdeen Royal Infirmary, UK

Address for correspondence: $\mathrm{Dr}$ Anna Biscoe

Aberdeen Royal Infirmary, Foresterhill, Aberdeen AB25 2ZN, UK.

Tel: +44 (0)345 4566000

E-mail: anna.biscoe@nhs.net

Br J Diabetes 2016;16:202-205

http://dx.doi.org/10.15277//bjd.2016.111
Figure 1. (A) Coronal CT scan demonstrating marked diffuse stranding within the subcutaneous tissues extending along the entire length of both legs. (B) Axial CT scan showing extensive stranding within both flanks and involving the muscle planes of the left abdominal wall. (C) Axial CT scan of the lower legs showing a fluid-filled bulla arising from the medial aspect of the left lower leg.

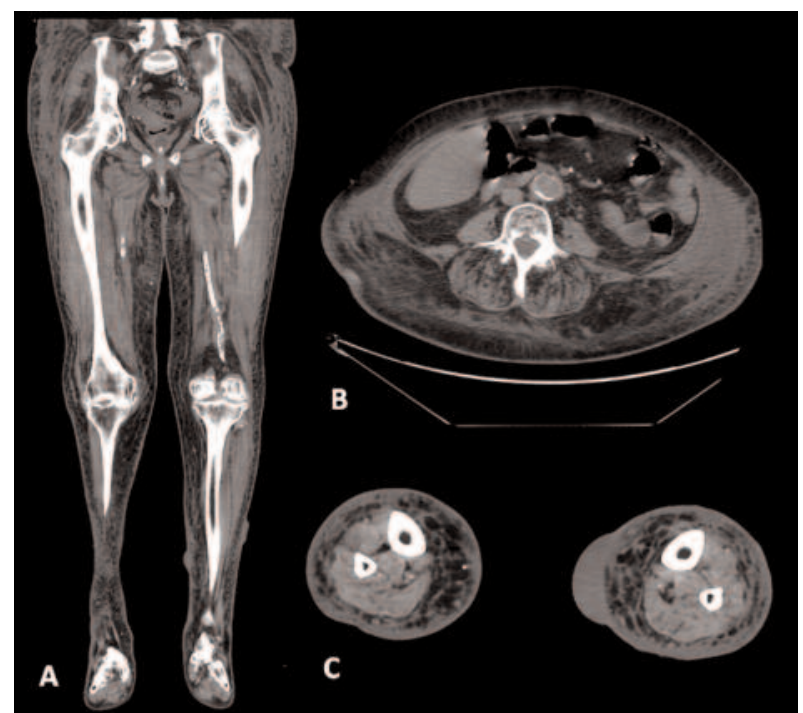

An emergency CT scan demonstrated marked diffuse stranding within the fat subcutaneously and within muscle planes, particularly affecting the left flank but extending along the entire length of both legs. Multiple fluid-filled bullae were seen in the distal left leg (Figure 1).

Sepsis 6 protocol was initiated and the patient was transferred to the high dependency unit (HDU) after commencing intravenous piperacillin-tazobactam and clindamycin for sepsis secondary to soft tissue infection, but she continued to deteriorate and remained hypotensive despite fluid resuscitation. She also developed haemorrhagic bullae extending to her thighs. Blood cultures were positive for gram-negative bacilli and piperacillin-tazobactam was therefore changed to meropenem.

An urgent plastic surgical review recommended conservative non-surgical management due to her significant comorbidities.

She continued to be managed on the HDU and her cellulitis 
Table 1 Results of a literature review for cases of soft tissue infection caused by Serratia marcescens as a single pathogen in adult patients

\begin{tabular}{|c|c|c|c|c|c|c|}
\hline $\begin{array}{l}\text { Case } \\
\text { no (ref) }\end{array}$ & Year & $\begin{array}{l}\text { Age }(y) / \\
\text { sex }\end{array}$ & Underlying condition and/or risk factor & Site of infection & Presentation & $\begin{array}{l}\text { Antibiotic } \\
\text { therapy/outcome }\end{array}$ \\
\hline $1(4)$ & 1977 & $51 / \mathrm{M}$ & Idiopathic cardiomyopathy, chronic leg oedema & Left lateral thigh & $\begin{array}{l}\text { Cellulitis, } \\
\text { septic shock }\end{array}$ & $\begin{array}{l}\text { Nafcillin, gentamicin } \\
\text { Died }\end{array}$ \\
\hline $2(5)$ & 1983 & $60 / \mathrm{M}$ & Peripheral neuropathy, steroid use, left leg trauma & Left calf & $\begin{array}{l}\text { Cellulitis, } \\
\text { septic shock }\end{array}$ & $\begin{array}{l}\text { Nafcillin, gentamicin } \\
\text { Recovered }\end{array}$ \\
\hline $3(6)$ & 2005 & $74 / \mathrm{M}$ & NSAID drug use & Leg & $\begin{array}{l}\text { Necrotising } \\
\text { fasciitis }\end{array}$ & $\begin{array}{l}\text { Not reported } \\
\text { Died }\end{array}$ \\
\hline $4(7)$ & 1988 & $71 / F$ & Healthy, left hand injured with a wire & Left hand & Cellulitis & $\begin{array}{l}\text { Gentamicin } \\
\text { Recovered }\end{array}$ \\
\hline $5(7)$ & 1988 & 23/M & Healthy & Dorsum of right digit & Cellulitis & $\begin{array}{l}\text { Gentamicin } \\
\text { Recovered }\end{array}$ \\
\hline $6(7)$ & 1988 & $52 / \mathrm{M}$ & Diabetes mellitus, diabetic foot ulcer & Right great toe & Cellulitis & $\begin{array}{l}\text { Cefotaxime } \\
\text { Amputation of } \\
\text { great toe, recovered }\end{array}$ \\
\hline $7(8)$ & 1991 & $88 / \mathrm{F}$ & Chronic venous dermatitis and lower leg ulceration & Left leg & Cellulitis & $\begin{array}{l}\text { Cefazolin, ciprofloxacin } \\
\text { Recovered }\end{array}$ \\
\hline $8(8)$ & 1991 & $60 / \mathrm{M}$ & Chronic venous dermatitis & Left lateral malleolus & Cellulitis & $\begin{array}{l}\text { Ciprofloxacin } \\
\text { Recovered }\end{array}$ \\
\hline $9(9)$ & 1992 & $37 / F$ & Chronic renal failure on haemodialysis & Right axilla & $\begin{array}{l}\text { Cellulitis, } \\
\text { septic shock }\end{array}$ & $\begin{array}{l}\text { Ciprofloxacin, vancomycin } \\
\text { Recovered }\end{array}$ \\
\hline $10(10)$ & 1996 & $55 / F$ & Diabetes mellitus & Right leg & $\begin{array}{l}\text { Necrotising } \\
\text { fasciitis }\end{array}$ & $\begin{array}{l}\text { Ceftizoxime, clindamycin } \\
\text { Recovered }\end{array}$ \\
\hline $11(11)$ & 1998 & $69 / F$ & Vascular disease, ingrowing nail removal & Lower leg & Cellulitis & $\begin{array}{l}\text { Clindamycin, gentamicin, } \\
\text { ciprofloxacin } \\
\text { Recovered }\end{array}$ \\
\hline $12(12)$ & 1999 & $66 / F$ & Healthy & Left leg & $\begin{array}{l}\text { Necrotising } \\
\text { fasciitis }\end{array}$ & $\begin{array}{l}\text { Clindamycin, penicillin G, } \\
\text { ceftriaxone, Died }\end{array}$ \\
\hline $13(13)$ & 1999 & $40 / \mathrm{M}$ & Lupus, renal failure, steroid use, skin biopsy & Lower leg & $\begin{array}{l}\text { Necrotising } \\
\text { fasciitis }\end{array}$ & $\begin{array}{l}\text { Penicillin G, ceftazidime } \\
\text { Recovered with } \\
\text { skin grafting }\end{array}$ \\
\hline $14(13)$ & 1999 & $73 / \mathrm{M}$ & Renal failure, steroid use & Lower leg & $\begin{array}{l}\text { Necrotising } \\
\text { fasciitis }\end{array}$ & $\begin{array}{l}\text { Penicillin, ciprofloxacin } \\
\text { Died }\end{array}$ \\
\hline $15(14)$ & 2002 & $81 / \mathrm{M}$ & Renal failure, vascular stasis, steroid use & Lower leg & Cellulitis & $\begin{array}{l}\text { Ceftaxolin, cefepime, } \\
\text { levofloxacin, Died }\end{array}$ \\
\hline $16(15)$ & 2004 & $49 / \mathrm{M}$ & $\begin{array}{l}\text { Immunocompromise due to chemotherapy for } \\
\text { metastatic small cell lung cancer }\end{array}$ & Right leg & $\begin{array}{l}\text { Necrotising } \\
\text { fasciitis }\end{array}$ & $\begin{array}{l}\text { Amoxicillin, piperacillin/ } \\
\text { tazobactam and amikacin } \\
\text { Survived }\end{array}$ \\
\hline $17(16)$ & 2005 & & $\begin{array}{l}\text { End stage renal failure, diabetes mellitus, heart failure, } \\
\text { scraping his leg on rocks in a river while fishing }\end{array}$ & Leg & $\begin{array}{l}\text { Necrotising } \\
\text { fasciitis }\end{array}$ & $\begin{array}{l}\text { Not available } \\
\text { Died }\end{array}$ \\
\hline $18(17)$ & 2012 & 97/F & $\begin{array}{l}\text { Right-sided heart failure with prolonged hospital } \\
\text { treatment, chronic kidney disease, atrial fibrillation }\end{array}$ & Right leg & $\begin{array}{l}\text { Necrotising } \\
\text { fasciitis }\end{array}$ & $\begin{array}{l}\text { Flucloxacillin and } \\
\text { amoxicillin, Died }\end{array}$ \\
\hline $19(18)$ & 2012 & $57 / F$ & $\mathrm{Cml}$ & Right thigh & $\begin{array}{l}\text { Necrotising } \\
\text { fasciitis }\end{array}$ & $\begin{array}{l}\text { Vancomyocin and } \\
\text { tazocin, Died }\end{array}$ \\
\hline $20(19)$ & 2013 & $50 / F$ & Snake bite & Right hand & $\begin{array}{l}\text { Cellulitis with } \\
\text { tissue necrosis }\end{array}$ & $\begin{array}{l}\text { Ciprofloxacin } \\
\text { Recovered }\end{array}$ \\
\hline $21(20)$ & 2014 & $75 / \mathrm{M}$ & Prostate carcinoma & Lower left limb & Cellulitis & $\begin{array}{l}\text { Vancomyocin and } \\
\text { tazocin } \\
\text { Amputations and recovery }\end{array}$ \\
\hline 22 & 2015 & $80 / F$ & Diabetes mellitus, chronic renal failure & $\begin{array}{l}\text { Lower left and later } \\
\text { right limb }\end{array}$ & $\begin{array}{l}\text { Haemorrhagic } \\
\text { cellulitis }\end{array}$ & $\begin{array}{l}\text { Tazocin, clindamycin, } \\
\text { meropenem } \\
\text { Died }\end{array}$ \\
\hline
\end{tabular}


gradually resolved. On day 4 blood cultures isolated S. marcescens. Her cellulitis improved sufficiently to be stepped down from the HDU. She required tissue viability input for local debridement of necrotic tissue around the calf. Unfortunately on day 50 of her admission she died due to intractable heart failure and pulmonary oedema.

\section{Discussion}

S. marcescens is a gram-negative Enterobacteriaceae of the genus Serratia. ${ }^{1}$ It is implicated in a wide range of serious infections most commonly of the lower respiratory tract, urinary tract, bloodstream, wound and meninges. ${ }^{1,2}$ It is also a rare cause of endocarditis and soft tissue infections. ${ }^{1}$

In recent years $S$. marcescens has been increasingly recognised as an important opportunistic pathogen. In this vein, it is most commonly recognised as a nosocomial infection especially in immunocompromised hosts and in the intensive treatment unit (ITU) setting. ${ }^{3}$ However, it has been estimated that almost half of $S$. marcescens bacteraemias (47\%) originate in a community setting. ${ }^{3}$

We conducted a literature search for community acquired soft tissue infections caused by S. marcescens using Medline (search criteria: S. marcescens, soft tissue infection, cellulitis, necrotising fasciitis, limited to English language) and found 21 other reported cases, as shown in Table 1.4-20 In all but four cases the hosts were immunocompromised or had an infected wound source, and in three cases the risk factor for contracting S. marcescens was diabetes mellitus.

While there are no specific clinical signs which are pathognomonic of $S$. marcescens soft tissue infection, the clinician should be more suspicious of $S$. marcescens in those patients with risk factors such as immunosuppression, diabetes mellitus, renal disease and long-term steroid use. Common empirical management for soft tissue infections is flucloxicillin \pm benzylpenicillin. However, if the cellulitis is severe or there is bullous disease, there should be a low threshold to consider gram-negative cover to include $S$. marcescens infection in this group of patients.

S. marcescens is naturally resistant to ampicillin, macrolides and first-generation cephalosporins. ${ }^{2}$ Furthermore, extended spectrum beta-lactamases (ESBL) are produced by most $S$. marcescens strains, which make them resistant to third-generation cephalosporins. ${ }^{1,2}$ In addition, fluoroquinolones have limited use in severe infection and should only be used in uncomplicated urinary tract infections where sufficient concentrations can be achieved in the urine. ${ }^{2}$

Gentamicin had been used as a single agent during the 1970s but increasing resistance in up to $50 \%{ }^{1}$ of cases meant that it is no longer used as a single agent. ${ }^{1,14}$ With the cessation of its use resistance has fallen to an estimated $6 \%$, but it is still not used as a single agent due to its propensity for resistance. ${ }^{1}$

Third-generation cephalosporins have been used as single agents, but this selects for resistant strains such as Ampicillin class $\mathrm{C}(\mathrm{AmpC})$ beta-lactamases and ESBL.1,14 This approach is therefore no longer favoured. They have been used alongside aminoglycosides, but there are reports of this failing to prevent the emergence of resistant strains. ${ }^{1}$

Fourth-generation cephalosporins or piperacillin-tazobactam are



- Serratia marcescens is a rare but, important cause of severe soft tissue infection in immunocompromised and diabetic patients

- One should have a low threshold for adding gram negative cover if patient is very unwell or develops bullous disease

- Cases should be escalated early to plastics if necrotising fasciitis is suspected

- Consider use of carbepenems in suspected Serratia marcescens infection. However, definitive therapy should be based on the results of susceptibility testing because multi-resistant strains are common

an effective treatment option where resistance to third-generation cephalosporins is evident or likely to develop. ${ }^{1}$ They are active against AmpC chromosomal beta-lactamase-producing strains but are still not effective against ESBL-positive isolates. ${ }^{1}$

Most often the antibiotics of choice are carbapenems, which remain active against bacteria expressing high levels of AmpC and ESBL. 1,2,14 However, as has been seen with other coliforms, there is evidence for the emergence of carbapenemase-producing strains against which these will be ineffective. ${ }^{1}$ As such definitive therapy should be based on the results of susceptibility testing because multiresistant strains are common..$^{1,12}$

Mortality from S. marcescens bacteraemia is high, with approximately one-third of patients dying within 6 months of diagnosis. ${ }^{3}$ Early debridement is indicated and appropriate antibiotic and supportive care are the cornerstones of therapy in severe soft tissue infection due to $S$. marcescens. Early surgical review and escalation to ITU/HDU care is vital.

\section{Conflict of interest None. \\ Funding None.}

Acknowledgements The authors acknowledge Fiona Caswell, Radiology Registrar at Aberdeen Royal Infirmary.

\section{References}

1. Herra C, Falkiner FR. Serratia marcescens. Cited 8 June 2015. Available at: http://www.antimicrobe.org/b26.asp.

2. Anía BJ. Serratia medication. Cited 8 June 2015. Available at: http://emedicine.medscape.com/article/228495-medication\#1.

3. Rehman T, Moore TA, Seoane L. Serratia marcescens necrotizing fasciitis presenting as bilateral breast necrosis. J Clin Microbiol 2012;50:3406-08. http://dx.doi.org/10.1128/JCM.00843-12

4. Brenner DE, Lookingbill DP. Serratia marcescens cellulites. Arch Dermato/ 1977; 113:1599-600. https://doi.org/10.1001/archderm.1977.01640110119023

5. Bonner MJ, Meharg JG. Primary cellulitis due to Serratia marcescens. JAMA 1983;250:2348-9. https://doi.org/10.1001/jama.1983.03340170074034

6. Rimailho A, Riou B, Richard C, Auzepy P. Fulminant necrotizing fasciitis and nonsteroidal anti-inflammatory drugs. J Infect Dis 1987;155:143-5. https://doi.org/10.1093/infdis/155.1.143

7. Kaplan H, Sehtman L, Ricover N, Slatkis D, Lacentre E. Serratia marcescens: cutaneous involvement. Preliminary report. Med Cutan 
